DOI: https://doi.org/10.30525/978-9934-26-081-0-12

\title{
REGULATION OF THE BANKING SERVICES SECTOR: ECONOMIC CONTENT, THE NEED FOR TRANSFORMATION, LEGAL SUPPORT
}

\section{Mursalov Muslim Mursal}

Ph.D. in Economics, Senior Lecturer at the Department of Economic Regulation of the Azerbaijan State University of Economics (UNEC) Baku, Azerbaijan

Banking institutions play a decisive role in the efficient allocation of investments and savings in a market economy and are important for the stability of the entire financial system. New phenomena in the economy, its information support and the use of digital technologies have a great influence on the banking sector.Under these conditions, the importance of strategic choice and the search for new priority models for the development of the banking business is growing. All this implies the emergence of new challenges for regulators. Regulation of a complex combination of technological and competitive changes taking place in the banking sector can be adequately carried out only if the peculiarities of 
innovative activity in this segment of the economy are properly taken into account. Its dramatic pace leads to the fact that the actions of regulators, as a rule, are delayed and do not fully take into account the circumstances of the new reality. In this regard, the problem of transformation of banking regulation and the search for effective mechanisms for its implementation seems to be very urgent.

The significant economic role, as well as the high-risk nature of banking, necessitate its regulation [1, p. 20-22]. Banking regulation and supervision is essential to its effective functioning. There is an active discussion in the scientific and economic literature about the definition of banking regulation and its differences from banking supervision and control. Most of the authors of the post-Soviet countries consider banking regulation as a system of measures by which the state through the Central Bank ensures the stable and safe functioning of banks, and also prevents destabilizing tendencies [2, p. 45; 3, p. 257; 4, p. 48; 5, p. 51]. According to a number of authoritative Russian scientists O. Lavrushin and $\mathrm{S}$. Moiseev, banking regulation is a set of administrative and economic measures aimed at organizing and ensuring the stability of credit institutions, protecting the interests of depositors and creditors in accordance with the goals and objectives of the monetary policy of the state $[6$, c. $319 ; 7$, c. 453]. Foreign researchers in most cases interpret the concept of banking regulation through the lens of goals that it helps achieve (for example, market transparency [8], preventing bank bankruptcy, eliminating information asymmetry [9], minimizing moral damage, financial security [10]). At the same time, some emphasize that the role of banking regulation and supervision is to create an environment that supports only reliable and law-abiding banks, thereby reducing excessive risks $[11 ; 12]$. Thus, one can conclude that there is no uniform interpretation of the concept of «banking regulation», which complicates their understanding and practical application. In our opinion, only in the aggregate of banking regulation and supervision can positive results be achieved in ensuring the financial stability of the banking sector.

Although banking regulations in different countries are highly heterogeneous, their competent authorities tend to share common goals and objectives. The generalization of world and domestic theory and 
practice makes it possible to distinguish the following as the main ones: (a) the development and strengthening of the banking system; b) ensuring sustainable and reliable functioning of the banking sector; c) achieving fair competition; d) protecting the interests of consumers of banking services; e) monetary control; e) lending to priority sectors of the economy; g) continuity of money circulation, continuity of payments and interbank settlements; h) minimization of risks-systemic, fraud, involvement of banks in criminal activities, etc.

The theoretical justification of the need for the development of banking regulation made it possible to systematize and disclose the content of the main factors that have the most important influence on the transformation processes. The transformation of banking regulation is carried out with the interaction of a number of economic agents: banks, regulators and other interested parties. Regulators, when making decisions in this area, follow the public interest, the influence of individuals or respond to the current situation in the banking sector. Modern changes in banking regulation at the national and supranational levels is more geared towards reducing excessive risks taken by banks, preventing incentives for market crises and improving risk management procedures $[13 ; 14 ; 15]$. The post-crisis view on the substantiation of the processes of transformation of banking regulation is characterized by the introduction of new provisions. This is primarily the movement of the regulatory process, mainly into a supranational dimension, which makes it difficult to influence national regulators. In addition, the importance of this transformation is growing in the context of the financial crisis, which contributed to increased involvement of stakeholders that have not yet been actively involved in regulatory activities. Innovations in regulation are aimed at bringing existing regulations in line with the new conditions. Among the factors justifying the need to transform banking regulation are also digitalization, the emergence of «bubbles» in financial markets, the presence of problem loans, shadow banking, economic recession, demographic trends. The above problems require preventive measures to regulate the banking sector. In a changing economic environment, as a result of the influence of digital technologies and the instability of the economic development of States, the building of new regulatory strategies and more effective 
organization of banking itself become fundamental factors. Aware of the need for further transformation of banking regulation and trying to limit the impact of new risks, regulators are now increasing their requirements for banking capital, improving the regulation of systemic risks and the activities of systemically significant banks, and also offering a new regulatory regime for working with structured products.

One of the key drivers of the transformation of banking regulation is its international legal support. Currently, the regulatory framework for banking regulation at the national level is common, largely based on international standards, which are considered the recommendations of the Basel Committee on Banking Supervision (Basel I-III). Post-crisis regulatory reform has significantly strengthened international and national banking systems, significantly improved the quantity and quality of banking regulatory capital, and increased the resilience of banks to market shocks. Progress can also be seen in such areas as regulation of systemically important financial institutions, crisis management, shadow banking, financial market infrastructure and derivatives [16; 17]. Although the Basel Standards differ best practices, as shown by domestic and foreign practices, especially in emerging markets, are accompanied by certain deviations, the basis of which lies in the context of continuing macroeconomic instability that limits compliance with standards. Future efforts to revise capital adequacy standards should both comply with basic standards of due process and ensure minimal information asymmetry.

\section{References:}

1. Banking Supervision: European Experience and Russian Practice. EU-Russia Cooperation Programme. Ed. by M. Olsen. Moscow: Bank of Russia, 2005. xxii, $318 \mathrm{p}$.

2. Jeffektivnost' sistemy regulirovanija bankovskogo sektora i potrebnosti nacional'noj jekonomiki: monografija [The effectiveness of the banking sector regulation system and the needs of the national economy: monograph]. Ed. by I.V. Larionovoj. Moskow: KNORUS, 2017. 171 p. (in Russian)

3. Ermakov S.L. (2012) Osnovnye voprosy bankovskogo regulirovanija i bankovskogo nadzora [The main issues of banking regulation and supervision]. Baikal Research Journal. № 3. P. 256-268. (in Russian) 
4. Nelidov P.A. (2017) Obosnovanie neobhodimosti bankovskogo regulirovanija i nadzora [Substantiation of the need for banking regulation and supervision]. $A C A D E M Y$. № 1 (16). P. 47-51. (in Russian)

5. Lauts E.B. (2008) Rynok bankovskih uslug: pravovoe obespechenie stabil'nosti. Uchebnik [Banking Services Market: Legal Stability. Textbook]. Moskow: Wolters Kluwer, 280 p. (in Russian)

6. Bankovskoe delo: uchebnik [Banking: textbook]. Pod red. O.I. Lavrushina. Moskow: KNORUS, 2016. 800 p. (in Russian)

7. Moiseev S.R. (2015) Istorija central'nyh bankov i bumazhnyh deneg [History of central banks and paper money]. Moskow: Veche. 536 p. (in Russian)

8. Benjamin J. (2007) Financial Law. Oxford: Oxford University Press. 710 p.

9. Hill J. (2018) Fintech and the Remaking of Financial Institutions. London: Academic Press. 386 p.

10. Schooner H.M., Taylor M.W. (2010) Global Bank Regulation: Principles and Policies. Burlington: Academic Press. xxiv, 326 p.

11. Barth J.R., Gan J., Nolle D.E. (2009) Global Banking Regulation \& Supervision: What Are the Issues and What Are the Practices?. Hong Kong: Cheung Kong Graduate School of Business. 88 p. Retrieved from: https://www.ckgsb.edu.cn/ Userfiles/doc/BARTH nolle\% 20gan_bood.pdf (accessed 23 May 2021).

12. Llewellyn D.T. Some Lessons For Bank Regulation From Recent Crises. Open Economies Review. 2000. Vol. 11. P. 69-109.

13. Basel Committee on Banking Supervision: Basel III: A global regulatory framework for more resilient banks and banking systems. Basel: BIS, 2011. 69 p.

14. Young, K. (2013) Financial industry groups' adaptation to the post-crisis regulatory environment: Changing approaches to the policy cycle. Regulation \& Governance. No. 7. P. 460-480. doi: 10.1111/rego.12025

15. Kara, G. (2016) Explaining cross-country and over-time differences in bank capital regulations. Finance and Economics Discussion Series 2016-057. Washington: Board of Governors of the Federal Reserve System, 40 p. doi: 10.17016/FEDS.2016.057.

16. Implementation and Effects of the G20 Financial Regulatory Reforms. 2020 Annual Report. Financial Stability Board. 13 November 2020. 22 p.

17. Gonzalez-Paramo J.M. (2018) Opportunities and challenges for banking regulation and supervision in the digital age. The European Money and Finance Forum. SUERF Policy Note Issue. April 2018. No. 31. 6 p. 